\title{
Editors' Introduction: Journal of Cognitive Historiography
}

\section{Esther Eidinow ${ }^{1}$}

University of Nottingham

esther.eidinow@nottingham.ac.uk

\section{Luther H. Martin²}

University of Vermont

luther.martin@uvm.edu

In 1965, Chester Starr wrote in his History of the Ancient World that if one is to understand "any era of the past one must be able to penetrate into the minds of its inhabitants" (Starr 1965: 27). However, how we access those dead minds is a perennial question, primarily because of the absence of any effective methodology for doing so. Historians have tended to base their understandings of the past solely on analyses that emphasize the external influence of physical, social, and cultural environments on minds as a sufficient explanans, or they have depended implicitly on shared folk-models of motivation and reasoning, and/or appealed rhetorically to a shared "common sense". However, the increasing interest that has been shown by some classicists, ancient historians, historians of religion, historians

1. Esther Eidinow is Lecturer in Ancient Greek History in the Department of Classics at the University of Nottingham. She has published widely in the field of ancient Greek religion, including Oracles, Curses, and Risk Among the Ancient Greeks (2007, repr. 2013) and Luck, Fate and Fortune (2011).

2. Luther H. Martin is Professor Emeritus of Religion, University of Vermont. He also has been a Distinguished International Fellow at the Institute of Cognition and Culture, Queen's University Belfast, and a Visiting Professor at Masaryk University, Brno, Czech Republic. He is the author of Hellenistic Religions (1987) and of numerous articles in this field of his historical specialization. He has also published widely in the field of theory and method in the study of religion, especially, in the area of cognitive theory and historiographical method, and has co-edited several volumes in this area, including Past Minds: Studies in Cognitive Historiography (2011). He is now a founding member the International Association for the Cognitive Science of Religion and is coeditor of its Journal of the Cognitive Science of Religion. 
and literary scholars in recent advances in evolutionary, cognitive and neuroscientific theorizing indicates that these familiar routines are themselves becoming a thing of the past. And this, in turn, suggests the need for a journal focused on exploring the possibilities offered by cognitive approaches to the study of historical evidence - that is, a Journal of Cognitive Historiography.

Cognitive theorizing is itself a youthful discipline that crosses multiple subject boundaries: cognitive research is being conducted, within its evolutionary frame, in and across such fields as philosophy, religion, psychology, anthropology, sociology and neuroscience, among others. Across this broad, interdisciplinary field, a common research agenda pursues the universality of human brain morphology and the mapping of its common mental functions. The cognitive insights that result present scholars in the Humanities with a new set of tools with which to approach historical data. Since the foundation of historiography as a discipline in the nineteenth century, the question of how to present the general vs. the particular, cause vs. description, facts vs. feelings, has never ceased to be at issue. But "the cognitive turn" breaks down existing research methods, and sets us on the trail of historical minds, prompting us to identify alternative ways to consider existing questions, and offering potential methods for formulating new ones.

The idea is seductive: attempts to understand the minds of Homo sapiens have been a perennial occupation of our species, at least from the Paleolithic era - if David Lewis-Williams (2002) is correct in his analysis of the enigmatic cave paintings of southern Europe. In terms of what it means for our approach to writing history, we can trace historiographical innovations informed by evolutionary and cognitive theorizing back to the late nineteenth century. By 1882, for example, the Dublin anatomist Alexander Macalister sought to understand Darwinian "laws" of evolution as universal laws of history as well (Macalister 1882: 4). His case study was drawn from the history of religions, namely, the history of Christianity. Religion was also the focus of the Cambridge classicist Jane Harrison, who, anticipating the agendas of contemporary evolutionary psychology and cognitive science, and following Darwin's own expectations for the future of psychology, proposed a history of religion that would focus on "the necessary acquirement of each mental capacity [for specific religious practices and ideas] by gradation" (Harrison 1909: 497; Darwin 1859 [2003: 458]).

By the early twentieth century, in other words, both a (social) evolutionary and a (proto-) cognitive approach to the study of history had been proposed. However, a growing body of ethnographic evidence increasingly challenged popular views of socio-cultural development as progressively adaptive, while 
the rediscovery of Mendel's laws of heredity challenged analogies of biological heredity to historical transmission by showing that natural selection was neither the mechanism whereby variations were produced, as they had assumed, nor their source (Tax and Krucoff 1968: 404-405). Little of this human preoccupation with minds was systematically carried over into historiographical methodology - apart, of course, from now contested psychoanalytical models, e.g., Erik Erickson's study of Martin Luther (1958). Furthermore, first person accounts, upon which traditional folk as well as theoretical models have been constructed, have now been contested by contemporary research into brain functioning (Berthoz 2006).

It was not until 1989 that a group of biologists, historians, and philosophers gathered in Chicago to reconsider the implications of contemporary, i.e., postMendelian or neo-Darwinian, evolutionary theory for historical methods. Their conclusions were published in 1992 in a volume entitled History and Evolution (Nitecki and Nitecki). Subsequently, the journal History and Theory published a theme issue in 1999 on "The Return of Science: Evolutionary Ideas and History" (Shaw and Pomper 1999) that continued and extended the discussions of historical and cultural change as the products of evolutionary forces which had been initiated at the Chicago symposium a decade earlier. The reconsideration of conventional historiographical emphases on historical particulars, which began to appear in these discussions, focused on the expressions of evolved panhuman capacities of individual minds that had already been recognized by Harrison. These forays were matched by pioneering work in other fields: anthropologists and psychologists were exploring the relationship between the individual and culture through the lens of evolutionary and cognitive theories, while in the humanities, innovative work was being done using cognitive approaches to explore historical subjects and the literary texts they produced.

That the time is right to introduce this journal is suggested by the rising and increasingly sophisticated application of cognitive theories across history-focused disciplines. Just recently, cognitive theories have been used to examine Paleolithic art, the comprehension of literary narratives, micro-histories of small village communities, and macro-cultural analyses of the rise and fall of empires. Whereas some scholars have combined the disciplines to propose universal historical frameworks, others have tried to understand more deeply the mind of a single individual. While it is important to recognize that none of these proposals represent any sort of biological or cognitive determinism, evolutionary and cognitive universals and biases do provide a foundation for and constraints upon all varieties of socio-cultural constructions - in the words of evolutionary anthropologist Robin Dunbar, "a neural environment that is sensitive to 
certain kinds of cues when these are encountered" (Dunbar 2010: 65-66; see also Boyer 1994: 29). The possibilities and constraints afforded by such "neural" environments should be of as much concern to historians as are the environmental cues - physical, social, and cultural - with which they interact.

If this seems to be an excessively abstract way of studying the past, we should bear in mind that cognition and cognitive approaches root the abstract in the physical, the mind in the body and bodily experience. Mirroring its subject matter, "the cognitive turn" fully incorporates "the bodily turn", and vice versa. As well as employing cognitive insights and models in their historiographical work, historians, in turn, can productively participate in the cognitive project generally, by assessing the "real-life" validity of cognitive models. After all, if cognitive behaviours identified by evolutionary psychologists and cognitive scientists are, in fact, panhuman proclivities, then their effects should be readily documented from historical analyses.

This journal aspires to embrace the broad interdisciplinary swathe of historical and cognitive scholarship and to encourage novel interconnections. All submissions to the journal will, of course, be blind-reviewed, and beginning with the second issue of this journal, we will also regularly feature reviews of books by those attempting to integrate these fields. To further collaborative approaches between historians who are interested in incorporating insights from the cognitive sciences into their research and those working in the cognitive sciences that might be interested in historical research, we plan also to publish, from time to time, instructive commentaries by cognitivists on articles by historians - and vice versa.

We hope that those who have been working in this area for a while will find the journal a useful and productive place to test and explore ideas, and connect with other scholars who have similar open-minded interests; we wish those who visit out of curiosity to be stimulated and inspired. In this way, we aim to support collaboration in what is an experimental, interdisciplinary field, and we welcome contributions that take up the challenge to continue to build and shape it.

\section{References}

Berthoz, A. 2006. Emotion and Reason: The Cognitive Neuroscience of Decision Making. Oxford: Oxford University Press.

Boyer, P. 1994. The Naturalness of Religious Ideas: A Cognitive Theory of Religion. Berkeley, CA: University of California Press.

Darwin, C. 1859, repr. 2003. On the Origin of the Species by Means of Natural Selection, or the Preservation of Favoured Races in the Struggle for Life. London: John Murray [London: Routledge]. 
Dunbar, R. 2011. How Many Friends Does One Person Need? Dunbar's Number and Other Evolutionary Quirks. Boston, MA: Harvard University Press.

Erickson, E. 1958 Young Man Luther: A Study in Psychoanalysis and History. New York: 1958.

Harrison, J. E. 1909. “The Influence of Darwinism on the Study of Religions”, in Darwin and Modern Science: Essays in Commemoration of the Centenary of the Birth of Charles Darwin and of the Fiftieth Anniversary of the Publication of the Origin of the Species, ed. Albert C. Seward. Cambridge: Cambridge University Press.

Lewis-Williams, D. 2002. A Cosmos in Stone: Interpreting Religion and Society Through Rock Art. Walnut Creek, CA: Rowman Altamira.

Macalister, A. 1882. Evolution in Church History. Dublin: Hodges and Figgis.

Nitecki, M. H., and D. V. Nitecki. 1992. History and Evolution. Albany, NY: State University of New York Press.

Shaw, D. G., and P. Pomper, 1999. “The Return of Science: Evolutionary Ideas and History”, History and Theory. Theme Issue 38.

Starr, C. 1965. History of the Ancient World. New York: Oxford University Press.

Tax, S. and L. S. Krucoff. 1968. "Social Darwinism”, International Encyclopedia of the Social Sciences 14. New York: Macmillan Press, 402-405. 